\begin{tabular}{l|l}
$\mathbf{m} \boldsymbol{m}$ & south \\
asia
\end{tabular}

samaj multidisciplinary

uilu academic
South Asia Multidisciplinary Academic Journal

17| 2018

Through the Lens of the Law: Court Cases and Social Issues in India

\title{
A Journey to the Brink of India's Legal Landscape: Jammu and Kashmir's Relationship with the Indian Union
}

Jean-Philippe Dequen

\section{(2) OpenEdition}

\section{Journals}

Electronic version

URL: http://journals.openedition.org/samaj/4415

DOI: $10.4000 /$ samaj.4415

ISSN: $1960-6060$

Publisher

Association pour la recherche sur l'Asie du Sud (ARAS)

Electronic reference

Jean-Philippe Dequen, « A Journey to the Brink of India's Legal Landscape: Jammu and Kashmir's Relationship with the Indian Union », South Asia Multidisciplinary Academic Journal [Online], 17 | 2018, Online since 16 January 2018, connection on 30 April 2019. URL : http://journals.openedition.org/ samaj/4415; DOI : 10.4000/samaj.4415

This text was automatically generated on 30 April 2019.

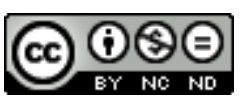

This work is licensed under a Creative Commons Attribution-NonCommercial-NoDerivatives 4.0 International License. 


\section{A Journey to the Brink of India's Legal Landscape: Jammu and Kashmir's Relationship with the Indian Union}

Jean-Philippe Dequen

\section{Introduction}

1 The construction of the independent Indian State was built on a plurality of pre-existing legal orders pertaining both to public law-whereby the multiple principalities under the paramountcy of the British Raj retained a wide legislative, executive and judicial autonomy-and private law, notably through a personal legal system under which different communities were subject to their respective norms within specific subject matters-mainly familial relations and the administration of religious institutions.

Despite this legal motley, India has managed over its relatively short history as an independent Nation-State to move towards uniformization. In this regard, uniformization does not imply strict uniformity. India being a federation, regional States were granted certain prerogatives in the legislative process relating to their areas of responsibility, ${ }^{1}$ whilst Parliament has also limited the scope of certain centralized acts so as to accommodate local specificities, as well as legitimizing non-State normative bodies. ${ }^{2}$ Notwithstanding the inherent diversity resulting from this architecture, the legal frame remains however within the canons of a modern State-which consists in a positivistic and hierarchical normative system, where sovereignty ultimately lies with the Indian people through the instrument of the Constitution and its unifying agency. ${ }^{3}$

In recent years, the concept of legal pluralism has enabled a newly founded academic debate on the actual effectiveness of this uniform frame, wondering if it was indeed India's founding fathers' initial intention. However, this discussion remains primarily fixated on implementation (or the lack of it) and the existence of alternative legalities 
(mainly through anthropological data)..$^{4}$ Little attention is in fact paid to State organized pluralism, which is the existence of duly recognized and competing sovereignties entrenched in a single positivistic legal frame.

Through the study of the peculiar status of the State of Jammu and Kashmir (hereafter J\&K) within the Indian Constitution, this article seeks to present such an instance of competing sovereignties, to then explore the repercussions of this particular institutional framework within the day-to-day judicial experiences of Kashmiri litigants in Srinagar. This approach thus insists on the importance of constitutional design within the broader elaboration-and unification-of civil law, ${ }^{5}$ and aims at demonstrating its direct impact on society within day to day litigation.

Hence, the legal architecture pertaining to the accession and subsequent status of J\&K within the Indian Union will first be presented, before exploring the latter's impact on the administration of disputes at the grass-root level, based on exploratory fieldwork undertaken by the author in Srinagar during the summer of $2012 .{ }^{6}$

\section{The place of Jammu and Kashmir within the Indian Constitution}

\section{The peculiar accession of Jammu and Kashmir to the Indian Union}

The dismemberment of the British Raj into two separate Dominions in 1947 left the former princely States with the option of either joining Pakistan or India. It is worth remembering that for the most part these States had the attributes of sovereign entities that had merely been under the protection of the British Empire. In fact, Jammu and Kashmir already had its own Constitution, ${ }^{7}$ detailing the executive, legislative and judicial powers of the Maharaja, whilst organizing the judiciary through a High Court and a "Board of Judicial Advisors" inspired by the British framework. ${ }^{8}$ When midnight struck on 15 August, J\&K had de jure full legislative and judicial powers, and as such could have asserted its own independence. ${ }^{9}$ The geopolitical situation of the time combined with Maharaja Hari Singh's indecision as to which Dominion to join decided otherwise. ${ }^{10}$ However, J\&K's sensitive geographical position between the newly formed Pakistan and India allowed it to wield more leverage as to its future status. The Instrument of Accession of Jammu and Kashmir (Teng, Bhatt, and Kaul 2006:227), which was rapidly accepted by Lord Mountbatten (then Governor General of the Dominion of India), had therefore to be taken into account in the drafting of the future Indian Constitution. ${ }^{11}$

Indeed, the Instrument of Accession states:

3. I [Maharaja Hari Singh] accept the matters specified in the schedules here to as the matters with respect to which the Dominion Legislature [of India] may make law for this State ...

6. Nothing in this Instrument shall empower the Dominion Legislature to make any law for this State authorizing the compulsory acquisition of land for any purpose ... 7. Nothing in this Instrument shall be deemed to be a commitment in any way as to acceptance of any future Constitution of India or to fetter my discretion to enter into arrangement with the Governments of India under any such future Constitution.

8. Nothing in this Instrument affects the continuance of my sovereignty in and over this State, ... or the validity of any law at present in force in this State (Teng, Bhatt, and Kaul 2006:227). 
8 The schedule only gives power to the Dominion in matters relating to defense, external affairs and communications. Moreover, it affirms that although India would be given jurisdictional powers over the aforementioned matters, it could only do so within the existing State court system, hence not recognizing any jurisdiction to a higher Dominion court (i.e. the Federal Court of India and the Privy Council).

9 Hence J\&K, although attached to India, retained most of its sovereignty, only transferring certain matters to the central State. At this stage, J\&K kept control over the status of its citizens $^{12}$ as well as jurisdictional monopoly over civil and criminal matters. ${ }^{13}$ Moreover, by not automatically recognizing the future Constitution of India, it enshrined the principle that the State would still be governed by its own constitutional framework. It was for the Constitution of India to uphold and regulate this dual system. ${ }^{14}$

10 As a consequence, only articles 1 and 370 of the Indian Constitution directly apply to J\&K, article 370 specifically dealing with the relations between J\&K and India:

1. Notwithstanding anything in this Constitution,

1. The provisions of article 238 shall not apply in relation to the State of Jammu and Kashmir

2. The power of Parliament to make laws for the said State shall be limited to

1. Those matters in the Union List and the Concurrent List which, in consultation with the Government of the State, are declared by the President to correspond to matters specified in the Instrument of Accession governing the accession of the State to the Dominion of India as the matters with respect to which the Dominion Legislature may take laws for that State; and

2. Such other matters in the said Lists as, with the concurrence of the Government of the State, the President may by order specify ... (Constitution of India 1950)

11 Hence, any extension of India's jurisdiction beyond what is already specified in the Instrument of Accession shall beforehand seek the approval of the State government and J\&K's own constituent assembly. ${ }^{15}$

12 As such The Constitution (Application to Jammu and Kashmir) Order, 1950 was issued, and extended Parliament's jurisdiction over matters in the Union List (Seventh Schedule, Constitution of India 1950), as well as the application of a number of articles of the Constitution. This resulted in a political crisis between the government of India and that of J\&K, ultimately solved by the Delhi Agreement of 24 July 1952 concluded by both governments, where the special status of J\&K was confirmed, along with its complete internal autonomy. ${ }^{16}$

13 The Constitution (Application to Jammu and Kashmir) Order, 1954 implemented this agreement with the approval of the J\&K government. While progressively extending ${ }^{17}$ the jurisdiction of Parliament and the Indian Constitution, it also amended or restricted the application of specific articles of the latter in regards to the specificity of J\&K. ${ }^{18}$

J\&K enacted a new Constitution in 1956, where it reiterated its inclusion within the Indian Union (art. 3). Yet the goal of this constitution is the "pursuance of the accession of this State $[J \& K]$ to India ..., to further define the existing relationship of the State with the Union of India as an integral part thereof" (Constitution of Jammu and Kashmir 1956: Preamble). As such, if J\&K is territorially an integral part of India, its legal integration on the other hand is still in "pursuance." In other words, the Constitution of India remains an extraneous norm which only applies by virtue of the Instrument of Accession, the Delhi Agreement and ultimately the J\&K Constitution. J\&K vows to be an integral part of India, 
benefiting from the latter's protection and advantages as rights, whilst picking and choosing the duties the "motherland" otherwise imposes on the rest of the country. ${ }^{19}$

How then can the relationship between India and the State of Jammu and Kashmir be defined? A dual constitutional system is at play here, where two distinct sovereignties have organized their relationship beyond the scope of federalism. Normative hierarchy is blurred, as the Constitution of India is but an empty vessel in regards to J\&K-where only the The Constitution (Application to Jammu and Kashmir) Order, 1954 holds force. Although modeled on and by the Indian Constitution, it is an entirely separate instrument in which both sovereignties have agreed to share and devolve power to one another.

\section{Jammu and Kashmir as a transitional State with sui generis status?}

Jammu and Kashmir's relationship with the Indian Union is not without similarities to other legal scenarios, which have for the most part grown out of de-colonization. However, it remains peculiar in many aspects, and does not find automatic parallels to other institutional frameworks linking one territory to another.

Indeed, it cannot be characterized as a free association of sovereign States, such as defined by the UN General Assembly Resolution 1541 (XV), 15 December 1960 in its Principle VII. ${ }^{20} \mathrm{~J} \& \mathrm{~K}$ does have its own constitution and both the Instrument of Accession and the Delhi Agreement could be qualified as "international" instruments, whilst as stated above the "individuality and cultural characteristics" of J\&K have been preserved within the Indian Constitution; however, if it kept part of its sovereignty, it is not independent as such and furthermore seeks to become an "integral part" of the Indian Union as per its own constitution whereby its citizens are Indian nationals themselves.

Notwithstanding, to seek greater integration is not the same as being integrated. As such, J\&K cannot be characterized as integrated into India under international law. Indeed, the latter would imply equal status between citizens of both territories (UN General Assembly 1960: principle VII), and as mentioned above J\&K's permanent residents are immune to article 14 of the Indian Constitution, whilst their privileges are not limited only to the acquisition of land, but also grant them priority for most local government jobs and the judiciary. Integration, although it is an aim, is therefore far from being a completed process.

This partial integration seems to be explained by a difference in legal treatment pertaining to J\&K's population on the one hand (permanent residents being fully incorporated to India through a common nationality), and its territory on the other (where India's sovereignty does not fully extend). Nonetheless, if such dichotomy can also be found within other legal architectures-such as that pertaining to Puerto Rico in regards to the United States-strong differences persist. Indeed, unlike J\&K and India, there is no reciprocity in the relationship between the United States and Puerto Rico. Any extension of US legal provisions does not need the concurrence of Puerto Rico's legislature. Unlike "free association," Puerto Ricans as US citizens do participate in US legal life, much like Kashmiris in relation to India. But Puerto Rico can hardly be considered a separate legal entity through which accession to the United States can be negotiated and formalized; the island is but a mere "possession" of the latter ${ }^{21}$ and if its population has acquired some rights, the territory in itself has not. 
In light of its post-colonial history, J\&K's status within the Indian Union is perhaps closer to another post-colonial experiment, namely France in relation to New Caledonia. Indeed, the latter occupies similarly a special place within the French Constitution, ${ }^{22}$ which was similarly the result of a negotiation process. ${ }^{23}$ Despite a radically different aim (New Caledonia heading towards self-determination and J\&K towards becoming an "integral part" of the Indian Union), similarities are nevertheless striking. Indeed, both frameworks have sprung out of inter-governmental agreements, which have in turn been incorporated into a constitutional framework resulting in sui generis statuses organized through special legal instruments (loi organique $n^{\circ} 99-209$ and Constitution (Application to Jammu and Kashmir) Order, 1954), granting citizenship (falling short of a nationality), within which are attached particular rights in regards to personal status and property, as well as a specific institutional architecture. ${ }^{24}$

21 J\&K's legal status within the Indian Union as sui generis remains by definition hard to grasp, as it does not easily fit into pre-conceived legal categories, whether through an international or comparative lens. Thriving towards integration within the Indian Union, it does however have the legal capacity to both limit its pace and retain some prerogatives. Notwithstanding, it remains for a large part virtual as far as implementation is concerned. One cannot ignore India's de facto political and military influence over the State. ${ }^{25}$ But India's de jure capacity to influence J\&K's legal order remains constrained, and this despite political pressure from the central government. ${ }^{26}$ Nevertheless, in their daily litigation over private matters, the people of J\&K find themselves forced to navigate between these different and sometimes contradictory constitutional frameworks.

\section{Snapshot of legal administration in J\&K: Indian influences and disparities}

The autonomy of J\&K within the Indian Union becomes apparent to outsiders visiting the State. Indeed, one soon realizes that Indian cell phones will not work in Kashmir, nor would one easily find an internet café as would be the case in any other large Indian city. ${ }^{27}$ Most familiar institutions (banks, insurance companies, coffee shops etc...) bear a local denomination and one fails to recognize the pan-Indian branches one expects in the capital of a regional State. However, the daily judicial inner workings of Srinagar do not induce a similar sense of "exoticism," as the proceedings follow their course much in the same manner as in the rest of India. Moreover, despite J\&K's gradual legal integration, there does not seem to be any reluctance on the part of Kashmiri litigants to trust and use what could be described as an "imported" judicial administration. Through exploratory fieldwork, which does not purport to be exhaustive nor generalizable, one can however point to a few hypotheses as to the existence of this apparent paradox, and its links to J\&K's status within the Indian Union.

\section{A legal integration intended to decrease the burden of pending cases}

24 As aforementioned, the judicial organization of $\mathrm{J} \& \mathrm{~K}$ is on a par with that of the rest of the country, consisting of Magistrate's Courts-hearing small claims and criminal matters 
(with the exception of narcotics), District Courts-competent for civil matters as well as narcotics-and a High Court, which itself is subordinated to the Indian Supreme Court. The Central Administrative Tribunal (which is competent notably in regards to tax litigation) is however based in Chandigarh and holds a two day session in Srinagar twice a month. J\&K has the particularity of having two capitals (Jammu and Srinagar) and as such, judges often travel from one location to the other. ${ }^{28}$

This judicial dichotomy only accentuates the burden the judiciary otherwise faces, especially at the lower level, where for instance the Magistrate's Courts deal with approximately 80 cases a day, a burden which forces the judges to multi-task during hearings-preparing the next case whilst listening to testimonies and arguments from another. ${ }^{29}$ According to the Chief Magistrate, this state of affairs can be explained both on procedural grounds, as every police statement must be confronted in open Court, and as a Kashmiri singularity whereby advocates' fees are calculated pro rata the number of appearances in Court, thus inciting them to ask for multiple continuances. The situation is different in Jammu, where fees are usually agreed upon in advance. ${ }^{30}$ This sometimes translates into slightly more "aggressive" pleadings by advocates in Srinagar, who sometimes put forward the illegitimacy of "Indian justice" in Kashmir. ${ }^{31}$

Nonetheless, the judicial system in Kashmir seems to be largely accepted by the population, as the sheer number of cases pending indicates. The latter is in fact the main concern of the judiciary, far ahead of ontological questions about its legitimacy. As such, alternative dispute resolution fora, such as the Muslim Court of the Mufti Azam of Kashmir, are more often than not used in conjunction with the official justice system, and not against it. ${ }^{32}$

A Senior Advocate from the J\&K High Court explains this general acceptance of the judicial system by arguing that the latter is in fact more British than Indian, furthermore pointing out that however "colonial" and "Christian" it may be, there was no other alternative model available at this stage. ${ }^{33}$ As aforementioned, both substantively and procedurally, J\&K's administration of justice had already been reformed along the British model before its integration within the Indian Union. In this regard, J\&K legal codes offer but minor differences compared to the Indian ones. Nonetheless, the fact that Indian statutes do not automatically apply in J\&K has allowed for a number of norms to still be enforceable in the State, whilst having been repealed in the rest of the country. This is notably the case in the field of family law. However, the growing legal substantive harmonization taking place in recent years has been met with scarce resistance. A recent example pertaining to enforceability of Muslim personal law in J\&K suggests that such implicit acceptance seems again to lie on the grounds of efficiency above all else.

India and J\&K have retained from the British Raj a personal legal system, under which in certain subject matters (mainly pertaining to family relations) the applicable law will be that of one's ascribed community rather than the territorial law of the State, unless expressly specified. The Muslim Personal Law (Shariat) Application Act, 1937 governs the family relations of Indian Muslims, regardless of any customs they might otherwise adhere to. ${ }^{34}$

However, the 1937 Act did not extend to J\&K, which had always recognized certain customs otherwise repugnant to Islamic law, particularly in matters of successionnamely the concept of Dokhtare Nashin under which a daughter who did not leave the familial home upon marriage is entitled to the same share as a son, and that of Pisar 
Pawarda recognized as full adoption. ${ }^{35}$ Unlike in India, J\&K’s personal legal system had never been harmonized based on religious affiliation.

A question then arose as to whether Islamic law could nonetheless override customary provisions based on the fundamental right to profess one's religion, secured by the Constitution of India (art. 25) and applicable to J\&K through the Constitution (Application to Jammu \& Kashmir) Order, 1954. In Mst. Khatji v. Abdul Razak Sufi (1977) the appellant contested the Pisar Pawarda status of the respondent and hence her share in her deceased father's estate, notably on the grounds that the Islamic law of succession should strictly apply and failure to for it do so would be an infringement upon her freedom of religion. However, the court qualified the right to profess one's religion as not absolute, the constitution itself providing that it could be modified so as to "[regulate] or [restrict] any economic, financial, political or other secular activity which may be associated with religious practice" (Constitution of India 1950: article 25 (2)(a)). Transfer of property upon inheritance being qualified as an "economic" activity, the court considered that J\&K enactments could override the application of Islamic law, notably in their recognition of custom as valid law under the Sri Pratap Jammu and Kashmir Laws Consolidation Act, 1977 [1920 AD].

31 Forty years later, and as an apparent sign of greater integration into the Indian legal framework, the State legislature would nonetheless adopt the J\&K Muslim Personal Law (Shariat) Application Act, 2007-an almost identical version of the central Act of 1937. ${ }^{36}$ Provisions recognized as valid under the Sri Pratap Consolidation Act (1977) are therefore repealed in so far as they are inconsistent with the 2007 legislation (s. 3), such as the aforementioned customary laws.

However, the reason behind the adoption of Muslim Personal Law as general law-and moreover the latter's overriding effect on customary law-does not appear to stem from the will for greater legal harmonization with the Indian legal order. Rather, its inception lies in an obiter dictum of Imtiaz Hussain J. In Yaqoob Laway and Ors v. Gulla and Anr (2005). The learned judge was faced with a case that was initiated in 1974 and dragged along for thirty years, notably because of the difficulty in determining both the applicability and the substantive provisions of customary law. ${ }^{37}$ After deciding the case Hussain J. went on to state:

The Court [J\&K High Court in a previous case] ${ }^{38}$ suggested that the legislature of the State should take an early opportunity of clearly expressing itself by means of proper enactment, whether in matters relating to succession and other matters which came up before the court of law from day to day Personal Law of the parties should be made applicable or custom and if so what should be that custom in a particular matter. It appears the State Legislature has not shown any response to the suggestion of the court. But since the problem is persisting one, it is high time the Legislature of the State may take not of the suggestions of the Full Court [sic] ( Yaqoob Laway and Ors v. Gulla and Anr 2005).

As the learned judge remarked, customary law had not been properly recorded and its determination was therefore prone to "endless litigation" (Yaqoob Laway and Ors v. Gulla and Anr 2005), given the likelihood of appeals. Although Hussain J. does not advocate for Muslim Personal Law to override customary law, the State legislature probably found it to be an easier solution than to order a compilation of all the customs prevalent in J\&K. The 2007 Act would then appear to have been drafted not so much with the intention of a greater legal integration with the Indian normative frame, but rather as a response to 
facilitate the treatment of the growing number of pending cases, which is confirmed to be the leading concern of both litigants and judicial officers at the ground level.

Therefore, in light of both its British origin and the goal of smoothening the administration of justice with greater legal certainty and security, the substantive legal integration of $J \& K$ into the Indian legal framework does not seem to be a problem for the ordinary Kashmiri litigant. The question of the applicable norm does in fact appear to matter far less than the one who enforces it: i.e. permanent residents.

\section{Who delivers justice, a Kashmiri affair}

Permanent residency in J\&K grants a legal person certain privileges regarding the acquisition of land and priority of employment within the State; a problem however inevitably arises as to if and when such status may be revoked. The question was put before the J\&K High Court in State of J\&K v. Sawhney (2003). Several cases were dealt with in this single judgment. All had in common the determination of the status of a woman who, whilst being born as a J\&K permanent resident, had married a non-resident. Prior decisions ${ }^{39}$ had considered that a married woman was deemed to take the domicile of her husband, and based on a territorial approach to permanent-residency, would hence automatically forgo her status and the rights it conferred. ${ }^{40}$ The decisions were challenged notably on the grounds of a breach of the fundamental right to equality recognized by the Constitution of India (art. 14). If the High Court confirmed the nonapplicability of the Constitution of India in regards to the determination of permanent residency, ${ }^{41}$ it nonetheless decided the case in accordance with its broad principle. Indeed, it considered that if permanent residency can be acquired through marriage, ${ }^{42}$ this could not be construed negatively so as to revoke the status of an already-recognized permanent-resident-by-birth. It further considered that the restrictions to the acquisition of immovable property by non-residents did not include inherited property (which is transferred but not acquired), given the over-riding nature of personal law in governing this specific subject matter.

The reasoning of the High Court demonstrates both the influence and ambivalence of J\&K's status within the Indian Union, and its repercussions on the minutest of disputes relating to "every day" litigation. If in fine this decision relaxes the scope of the permanent resident's status and its privileges, putting it on par with Indian constitutional principles, it does so through a rationale entirely internal to J\&K's legal order, thus enshrining the latter's autonomy. ${ }^{43}$ One could thus put forward the hypothesis that the High Court was in fact pursuing two distinct goals within its decision, whose repercussions far outreach the scope of land rights.

The first was to justify the status of permanent residents in regards to the Indian Constitution, for notwithstanding its effects on property, it also severely restricts the access of non-residents to administrative jobs, notably in the judiciary. Observations during fieldwork showed that despite sometimes "aggressive" pleading remarks, whereby "Indian laws" were argued to be "illegitimate," the impartiality of judicial officers was not however questioned. Moreover, several interviewees emphasized the importance of the administration of justice in J\&K being an internal affair, in other words to be decided amongst Kashmiris. This general impression does in fact transpire institutionally, as well as in the judiciary's relations with non-official adjudicating bodies. Indeed, as aforementioned, the relations between judges and the Court of the Mufti Azam are 
cordial: the former accepting alternative dispute resolution fora which would help alleviate the burden otherwise put on the Courts. In the same manner, the accent put on conciliation transpires institutionally, notably in the setting up of a "Women's Police Station" in 1998, specifically targeted at women who may be reluctant to give testimony in front of male police officers..$^{44}$ It deals almost exclusively with matrimonial disputes, and emphasizes the importance of out-of-Court settlements. As such, only 50 cases were transferred to the Magistrate's Court in 2011.

However, the second aim of the High Court judgment is to relax the otherwise stringent rules on appointments within the legal profession. For while the latter is reserved for permanent residents, this also has the adverse effect of diminishing the pool of potential applicants. For example, during the last round of nominations at the Magistrate level in 2010, out of 33 successful candidates, 5 were "fresh out of law school"-which although permissible under J\&K regulations, ${ }^{45}$ was not on par with the majority of other Indian States, which more often than not require a minimum of three years of legal practice. ${ }^{46}$ If the rationale for lowering the threshold was grounded on evidence that "the best talent which is available is not attracted to the judicial service" (India Judges' Association and Ors v. Union of India and Ors 2002), this mainly referred to the graduates of the newly founded National Law Universities, situated outside J\&K. As observed by the Chief Magistrate in Srinagar, the possible loss of permanent residency upon leaving J\&K only emphasized the problems of recruitment the lower judiciary otherwise faces, even as he complained of the sometimes poor representation litigants were offered. ${ }^{47}$ As such, contrary to superficial appearances, the High Court's decision in State of J\&K v. Sawhney (2003) seeks in fact to protect the existence of permanent residency, and indirectly one of its most important aspects: i.e. that the administration of justice in J\&K still be in the hands of Kashmiris.

\section{Conclusion}

In his famous ethnography of the French administrative Supreme Court (Conseil d'État), Bruno Latour (2010) defined Law as "fractal." Even within the minutest of disputes, Law's entirety was both engaged and indiscernible from the peculiar statutes or regulations invoked in any particular case. This article has sought to briefly show such fractality through the example of Jammu and Kashmir's legal relationship with the Indian Union. The status of J\&K within the Indian legal framework is indeed difficult to qualify according to comparative and international standards, and can at best be characterized as sui generis. Although the State is deemed to be an "integral part" of India, it nonetheless retains its own legal order and the Constitution of India does not fully apply on its territory. The duality of J\&K's legal order is however not limited to the realm of public law, but also enlists the private field, even at a grass-roots level within every day litigation. Exploratory anthropological fieldwork further tends to show how J\&K's growing substantive legal integration into the Indian legal framework is closely linked to and largely accepted through-on the assurance of being administered by Kashmiri judicial officers-the permanent residency status. Thus, the challenges and evolution the lower judiciary faces in the daily administration of justice cannot be separated from the overarching legal relationship between J\&K and the Indian Union. This further demonstrates how enquiries on the cultural and social aspects of Jammu and Kashmir cannot escape a study of its legality. 


\section{BIBLIOGRAPHY}

\section{International Instruments}

Treaty establishing cession by the French Republic to the Indian Union of the French establishments in India of 28 May 1956. [1956] INTser 12.

\section{Indian Central legislation and regulations}

Indian Penal Code. 1860. Act No. 45 of 1860.

The Punjab Laws Act. 1872. Act No. 4 of 1872.

The Oudh Laws Act. 1876. Act No. 18 of 1876.

Kazis Act. 1880. Act No. 12 of 1880.

Muslim Personal Law (Shariat) Application Act. 1937. Act No. 26 of 1937.

Constitution of India. 1950.

The Constitution (Application to Jammu and Kashmir) Order. 1950. C.O. 10, dated January 26, 1950.

The Constitution (Application to Jammu and Kashmir) Order. 1954. C.O. 48, dated May 14, 1954.

Hindu Marriage Act. 1955. Act No. 25 of 1955.

State Reorganization Act. 1956. Act No. 37 of 1956.

Armed Forces (Special Powers) Act. 1958 Act No. 28 of 1958.

Code of Criminal Procedure, 1973 Act No. 2 of 1974.

Armed Forces (Jammu \& Kashmir) Special Powers Act. 1990. Act No. 21 of 1990.

\section{Jammu and Kashmir legislation and regulations}

Sri Pratap Jammu and Kashmir Laws Consolidation Act. 1977. [1920 AD] Act No. 4 of 1977.

J\&K Code of Civil Procedure. 1977. [1920 AD] Act No. 10 of 1977.

Ranbir Penal Code. 1989. [1932 AD] Act No. 12 of 1989.

J\&K Code of Criminal Procedure. 1989. [1933 AD] Act No. 23 of 1989.

J\&K Constitution Act. 1996. [1939 AD] Act No. 14 of 1996.

J\&K Constitution (Amendment) Act. 2008. [1951 AD] Act No. 17 of 2008.

Constitution of Jammu and Kashmir. 1956.

Jammu and Kashmir Civil Service (Judicial) Recruitment Rules. 1967. Retrieved August 16, 2017 (http:// jkpsc.nic.in/pdf/INSTRUCTIONS_FOR_CANDIDATES.pdf).

J\&K Muslim Personal Law (Shariat) Application Act. 2007. Act No. 4 of 2007.

\section{French legislation}

Constitution du 4 octobre 1958.

Loi organique No. 99-209 du 19 mars 1999 relative à la Nouvelle Calédonie (1999). 


\section{Cases}

All India Judges' Association and Ors v. Union of India and Ors (1993) 4 SCC 288.

Downes v. Bidwell, 182 US 244 (1901).

India Judges' Association and Ors v. Union of India and Ors (2002) 4 SCC 247.

Kundan Lal v. District Magistrate and Anr, AIR 1970 J\&K 143.

Lakhanpal v. President of India and Ors, AIR 1961 SC 1519.

Mohd. Akbar Bhat v. Mohd. Akhoon AIR 1972 J\&K 105

Mst. Khatji v. Abdul Razak Sufi AIR 1977 J\&K 44.

Prakash v. Sahani AIR 1965 J\&K 83.

S. Mubarik Shah Naqashbandi v. I.T.O. AIR 1971 J\&K 58.

State of Jammu \& Kashmir and anr. v. Susheela Sawhney, AIR 2003 J\&K 83

Vishwa Lochan v. Union of India \& Ors, 2014, 7 SCC 707.

Yaqoob Laway and Ors v. Gulla and Anr 2005 (3) JKJ 122.

\section{Bibliography}

Abdel Haleem, Muhammad A.S., trans. 2004. The Qur'an. Oxford: Oxford University Press.

Agniel, Guy. 2008. "Statut coutumier Kanak et juridiction de droit vommun en Nouvelle Calédonie.” ASPECTS 3:81-96.

Ashai, Sehla. 2010. "The Jammu and Kashmir State Subjects Controversy of 2004." Drexel Law Review 2(2):537-55.

Faberon, Jean-Yves. 2012. Des Institutions pour un pays. La Nouvelle Calédonie en devenir. Aix en Provence: Presse Universitaire Aix-Marseille.

Fayyaz, Ahmed Ali. 2013. “Modi Seeks Debate on Article 370.” The Hindu, May 23.

French Government. 1988. Accords de Matignon-Oudinot sur la Nouvelle Calédonie du 26 juin 1988. Retrieved August 16, 2017 (http://www.mncparis.fr/uploads/accords-de-matignon_1.pdf).

French Government. 1998. Accords sur la Nouvelle-Calédonie signé à Nouméa le 5 mai 1998. JORF No. 121 du 27 mai 1998, p. 8039.

Gopal, Sarvepalli (ed). 1984. Selected Works of Jawaharlal Nehru. Second Series. Vol. 19. New Delhi: Jawaharlal Nehru Memorial Fund.

Haardt, Oliver. 2017. "The Federal Evolution of Imperial Germany and the Creation of the German Civil Code." Presented at the Jour Fixe of the Max Planck Institute for European Legal History, January 16, Frankfurt am Main.

Jammu and Kashmir. 2004. Jammu and Kashmir Permanent Resident (Disqualification) Bill, Legislative Assembly. 2004, 116 Jammu \& Kashmir Gov’t Gazette 2.

Kak, Sanjay [Director]. 2007. Jashn-E-Azadi [How We Celebrate Freedom].

Khan, Muhammad Ishaq. 1980. Freedom Movement in Kashmir, 1931-40. Delhi: Light and Life Publishers.

Latour, Bruno. 2010. The Making of Law: An Ethnography of the Conseil D'etat. Translated by A. Pottage and M. Brilman. Cambridge: Polity. 
Menski, Werner. 2008. "The Uniform Civil Code Debate in Indian Law: New Developments and Changing Agenda." German Law Journal 9(3):211-50.

Shetty, Jagannatha. 1999. National Judicial Pay Commission Report. Retrieved September 23, 2017 ( https://docs.google.com/viewer? $\mathrm{a}=\mathrm{v} \&$ pid=sites\&srcid=ZGVmYXVsdGRvbWFpbnx0aHVtbWFqaXxneDo2ODhkN2NhZWNjMGE5NWMy ) .

Teng, Mohan Krishen, Krishen Kaul Bhatt and Santosh Kaul, eds. 2006. Kashmir, Constitutional History and Documents. $2^{\text {nd }}$ Ed. Delhi: Light and Life Publishers.

UN General Assembly (XV). 1960. Resolution 1541 on Principles which should guide members in determining whether or not an obligation exists to transmit the information called for under article $73 e$ of the Charter. December 15. Retrieved January 16, 2018 (https://documents-dds-ny.un.org/doc/ RESOLUTION/GEN/NR0/153/15/IMG/NR015315.pdf?OpenElement).

\section{NOTES}

1. Subject matters regarding legislative competence have been organized by article 246 of the Constitution of India, and divided in its "seventh schedule" between a "Union list," a "State list" and a "Concurrent list." However, the central legislature retains residuary legislative power (article 248) and central statutes prevail over State enactments pertaining to "concurrent list" subject matters (article 254).

2. An example can be found in the Hindu Marriage Act, 1955 regarding the recognition of custom in the solemnization of marriage (section 7). Furthermore, the Constitution of India (Part IX) recognizes (albeit defining the extent of their power) Panchayats [Village councils] whilst the Kazis Act, 1880 has allowed regional States to nominate Kazis [Muslim judges] in densely Muslim populated areas, despite stripping them of any judicial or administrative powers (s. 4). A recent decision Vishwa Lochan Madan v. Union of India \& Ors (2014) has confirmed the purely advisory nature of both their judgments and legal opinions (fatwā).

3. This unifying agency is particularly pregnant within (non-binding) Part IV-“Directive Principles of State Policy" of the Constitution of India, especially article 44 relating to the creation of a "Uniform Civil Code." Although not formally established, Werner Menski (2008) argues that a certain level of harmonization has already taken place within the existing personal legal system, especially in relation to post-divorce maintenance.

4. Gopika Solanki (2011) for instance has defined the fora within which un-official law is defined and implemented as "doorstep courts."

5. The impact of constitutional set-ups on the creation of civil law has however been largely ignored by lawyers and historians alike, who tend to favor a more inductive approach, as oliver Haardt (2017) recently pointed out in his doctoral research in relation to German federalism in the $19^{\text {th }} \mathrm{C}$. and its links to the elaboration of the German Civil Code.

6. It consisted of semi-direct interviews with several judicial actors, non-participatory observation of judicial proceedings at the Magistrate, District and High-Court levels, as well as visits to several police stations in Srinagar. It also included an interview with the Mufti Azam of Kashmir regarding his non-official Muslim Court. The author wishes to thank all the interviewees for their warm reception, in particular that of Chief Magistrate R. Gupta and Principal district and session judge M. Shafi Ishan. The author also wishes to thank A. Ali (advocate) and R. Ahmad Bhat (prosecutor) for their help in moving around the city, and most importantly Justice H. Imtiyaz Hussain for organizing this fieldwork and without whom it couldn't have taken place, as well as the joint program "Just India" for its financial support. 
7. J\&K Constitution Act, 1996 [1939 AD], and J\&K Constitution (Amendment) Act, 2008 [1951 AD].

8. The Letters Patent conferred to the High Court on 10 September 1943 were modeled on the ones already in place within the Raj.

9. The drive to full independence has strong historical roots, and is still alive today as Sanjay Kak's (2007) documentary-film has shown.

10. The Maharaja's true intentions remain unclear when his government proposed a Standstill Agreement to both Pakistan and India on 12 August 1947 (Teng, Bhatt, and Kaul 2006:223). This was accepted by Pakistan in a telegram dated 15 August 1947 (Teng, Bhatt, and Kaul 2006:224); however, India asked for negotiations to take place in New Delhi. On 2 and 3 September, movements of armed men coming from Pakistan were spotted, and "forced" the Maharaja to make an Accession Offer to India on 26 October 1947 (Teng, Bhatt, and Kaul 2006:227) in exchange for military assistance. The Instrument of Accession was accepted by Lord Mountbatten on 27 October 1947 (Teng, Bhatt, and Kaul 2006:229).

11. The geopolitical position of Kashmir did not allow the Indian government to simply annex this princely state, as Sardar Vallabhbhai Patel (then Deputy Prime Minister of India) did for Junagadh in 1947 and threatened to do in Hyderabad in 1948, both geographically remote from Pakistan. Nor could it be simply incorporated within the constitutional framework after its promulgation, as was the case for Goa (annexed in 1961) and Pondicherry (de facto ceded by France to India in 1954, and de jure in 1961 through the Treaty establishing cession by the French Republic to the Indian Union of the French establishments in India of May 28, 1956).

12. Defined as "State Subjects" by the State Subject Definition Notification No. I-L/84 on 20 April 1927 (Teng, Bhatt, and Kaul 2006:74) by Maharaja Bahadur, incorporated in the Constitution of 1939.

13. J\&K indeed has its own Code of Civil Procedure, 1977 (1920 AD), Code of Criminal Procedure, 1989 (1933 AD) and Ranbir Penal Code, 1989 (1932 AD).

14. Proclamation of Maharaja Yuvraj Karan Singh on 25 November 1949. The next day the Indian Constitution was adopted by the constituent assembly.

15. However, article 370 remains in force even after the constituent assembly's dissolution (S. Mubarik Shah Naqashbandi v. I.T.O. 1971)-the President of India still retaining the authority to enact orders to apply or restrict the application of certain provisions of the Indian Constitution, following the same procedure, that is in concurrence with the Government of J\&K (Kundan Lal v. District Magistrate and Anr 1970), Lakhanpal v. President of India and Ors (1961).

16. See Sheikh Mohammad Abdullah's Statement to the Constituent Assembly on Delhi Agreement (Teng, Bhatt, and Kaul 2006:261), and Jawaharlal Nehru's statement in the Lok Sabha on 24 July 1952 (Gopal 1984:219).

17. Amendment Orders from 1954 up until today continue to be issued in order to further incorporate J\&K's legal frame into the Indian one. The Order of 1954 extended jurisdiction of Parliament to all the matters contained in the "Union List" within the Constitution of India, while granting J\&K a residuary power of legislation for matters not mentioned in the State and Concurrent lists (as such, there is no "State List" in regards to J\&K). The Supreme Court's jurisdiction was also extended to J\&K in exchange for granting the High Court of the State the power to issue writs in order to enforce fundamental rights (applicable in J\&K).

18. One of the most notable is the addition of article 35A, which recognizes the status of "permanent resident" of J\&K as being similar to one of "citizenship"-State of Jammu \& Kashmir and anr. v. Dr. Susheela Sawhney (2003)-preventing it from being declared void under the provisions of Part III (Fundamental Rights) of the Indian Constitution, namely art. 14 (right to Equality). Another example was to limit the scope of article 3 in regards to J\&K (empowering the central legislature to create or alter the boundaries of existing States-as it did in 1956 along ethnic and linguistic lines-see State Reorganization Act 1956). 
19. As an example, under the division between general and special laws, the J\&K Code of Criminal Procedure (1989) and Ranbir Penal Code (1989) (as special laws) would supersede the Indian Code of Criminal Procedure, 1973 and Indian Penal Code, 1860-general laws which were subsequently partly extended to J\&K under the "Concurrent list"-as amended by the Constitution (Application to Jammu and Kashmir) Order, 1954. J\&K is not the only State benefiting from special laws (hence nonresidents cannot buy land in Himachal Pradesh, whilst they can only buy small plots in Uttarakhand), but the difference lies in the fact that because of J\&K's specific constitutional status, the central legislature may not amend or repeal such special legislation without J\&K's prior approval.

20. This involves one independent State devolving part of its sovereignty to another (notably in the realm of defense, monetary and foreign policy), as is for instance the case between the Marshall Islands, Micronesia and Palaos with the United States.

21. Part of the Commonwealth of the United States (art. 4, s. 3, cl. 2 of the Constitution of the United States), it has been defined as "a territory appurtenant and belonging to the United States, but not a part of the United States" (Downes v. Bidwell 1901).

22. Articles 76 and 77 of the Constitution of 1958 have created a transitional legal status for the islands, defined as sui generis and organized through a special law (Loi organique n'99-209 du 19 mars 1999 relative à la Nouvelle Calédonie) which establishes both a citizenship (article 4) and personal customary civil status for the Melanesian population (articles 7 to 19). Furthermore, although State courts are competent to settle disputes under this particular status, their bench is composed differently in order to include "customary assessors" (art. 19).

23. In the form of a set of two agreements: Accords de Matignon, (French Government 1988) and Accords de Nouméa (French Government 1998).

24. For more on this subject, as far as private law is concerned, see Guy Agniel (2008) and JeanYves Faberon (2012) for an institutional perspective.

25. Notably through the special powers given to the Indian Army (and specifically its immunity from judicial action by State authorities) by the Armed Forces (Jammu and Kashmir) Special Powers Act, 1990-which has however only been extended to J\&K and was not conceived for this particular region, but for the North-Eastern part of the country (Armed Forces [Special Powers] Act, 1958).

26. A recent example was given by the Prime Minister of India Narendra Modi (then a candidate), who during the 2014 general election campaign called for a debate on article 370 of the Constitution of India (Fayyaz 2013).

27. One could however suspect the reasons are more connected to security and surveillance, rather than legal autonomy.

28. As such, upon following hearings at the High Court in Srinagar, one notices that some of the Justices are not present, but in Jammu, which both limits the number of hearings and incites the bench to be more assertive towards advocates-notably asking them not to "waste their time": non-participatory observation of High Court judicial proceedings, August 29, 2012, Srinagar.

29. Interview with Chief Judicial Magistrate Rajeev Gupta on August 27, 2012, Srinagar. Nonparticipatory observation of judicial proceedings at the Magistrate's Court on August 27 and 28, 2012, Srinagar.

30. Interview with Chief Judicial Magistrate (note 29). In that regard, he readily admits that certain cases can drag along for years (even though some are prioritized: in the case of older litigants, women, Scheduled Tribes and Castes, litigants from remote areas or those below the poverty line), and that the best way to "bury" a case consists in putting forward a lengthy list of witnesses, who as time goes on will have moved and become impossible to find. The question of inadequate police reports-which are binding in Court-has also been echoed by prosecutors (who are not part of the investigation process), whilst knowing that certain cases are not "winnable": informal interview with five prosecutors, August 28, 2012, Srinagar. 
31. Non-participatory observation of judicial proceedings (note 29). This argument was however rapidly rebuked by the Chief Magistrate, asking the advocate "not to bring politics into Court." However, the fact that it was made in a light-hearted manner suggests it was more of a delaying tactic than an outright disapproval of the judicial system as a whole.

32. Interview with Principal District and Session Court Judge Mohammad Shafi, August 27, 2012, Srinagar. The latter points to the practice of forum shopping by certain litigants, who would approach the Court more likely to grant them the outcome they wished for. Judge Shafi further remarked that it was not uncommon for litigants who previously sought a decision in the Muslim Court to then come to the official Court system. Meanwhile, the Mufti Azam of Kashmir stresses that his Court is not against the official judicial system, whilst nonetheless regretting the lack of knowledge of certain judges in regards to Islamic family legal issues: interview with the Mufti Azam of Kashmir, August 30, 2012, Srinagar. However, Judge Shafi did point out that the Shia minority but rarely uses the official justice system, "sorting things by themselves."

33. Interview with a Senior Advocate at the High Court, August 29, 2012, Srinagar.

34. Indeed, this Act repealed previous legislative provisions which recognized custom as a valid choice of law (notably s. 3 of the Oudh Laws Act [1876] and s. 5 of the Punjab Laws Act [1872]).

35. Under classical Islamic law, according to the Kur'ān a daughter would inherit only half of a son's share in his presence (K 4:11 see Abdel Haleem 2004:51), whilst full adoption is not recognized (but rather the concept of foster-parent [Kafala]-drawn from K 33:4-5 and K 93:6-11 see Abdel Haleem:266 and 425).

36. The differences lie in the legal treatment of agricultural lands (included in the scope of $J \& K$ Act [2007], excluded in the central one) and testate succession (on which the J\&K Act stays silent).

37. This case also revolved on matters pertaining to adoption, which surfaced upon the succession of the appellant's father and the qualification of the respondent as pisar pawarda.

38. Mohd. Akbar Bhat v. Mohd. Akhoon (1972).

39. Prakash v. Sahani (1965).

40. Hence certificates of permanent residency issued to women by the State would mention "valid until marriage."

41. As per Section 4 (j) of the Constitution (Application to Jammu \& Kashmir) Order 1954.

42. According to note III of the State Subject Definition Notification No. I-L/84 on April 20, 1927, under which: "The wife or a widow of a State Subject of any class shall acquire the status of her husband as State Subject of the same Class as her husband, so long as she resides in the State and does not leave the State for permanent residence out-side the State" (Teng, Bhatt, and Kaul 2006:74).

43. It is worth noticing that the J\&K political scene did not fully grasp this last point. Soon after the decision, the Jammu and Kashmir Permanent Resident (Disqualification) Bill (Jammu and Kashmir 2004) was put forward before the state legislature to reverse its effects. Although the bill ultimately failed to pass, it remains symptomatic of J\&K's position in regards to its integration into the Indian Union (see Ashai 2010).

44. As such, all officers in the Police Station are women (except the Deputy Chief): visit of "Women's Police Station," August 28, 2012, Srinagar.

45. Jammu and Kashmir Civil Service (Judicial) Recruitment Rules, 1967.

46. See All India Judges' Association and Ors v. Union of India and Ors (1993); however, the First National Judicial Pay Commission Report (known as the "Shetty Commission Report") in 1999 proposed to abolish the three year minimum practice requirement. Whilst the Supreme Court has accepted this recommendation (see India Judges' Association and Ors v. Union of India and Ors (2002), it remains controversial as some States continue to require candidates to at least be members of the Bar.

47. Interview with Chief Judicial Magistrate (note 29). 


\section{ABSTRACTS}

This paper seeks to briefly assess the place of Jammu and Kashmir within the Indian Union, as well as the latter's repercussions on the daily administration of justice in Srinagar. Although regional States have retained certain specificities and prerogatives under the Constitution of India, J\&K's status is significantly different. Being the only State with its own constitution, J\&K's accession to India has been achieved through specific legal instruments granting it a peculiar type of sovereignty. In order to define the relationship between India and J\&K, this article compares similar legal frameworks from a comparative perspective. It submits that J\&K belongs to a sui generis legal category, similar to the one New Caledonia currently enjoys within the French Republic. It then seeks to explore how this peculiar status interacts with the administration of justice at the grass-root level in Srinagar. It suggests that the overall acceptance of the judicial system in J\&K, as well as its growing integration into the Indian legal framework is closely linked to concerns about efficiency, and most importantly to the permanent residency status of its judicial officers.

\section{INDEX}

Keywords: India, comparative law, constitutional law, Muslim personal law, anthropology of law

\section{AUTHOR}

JEAN-PHILIPPE DEQUEN

Max Planck Institute for European Legal History 